\section{David W. Barkley}

David W. Barkley, professor emeritus of political science at Northeastern University, died suddenly on August 9, 1993, in Westwood, Massachusetts. He had just moved to Westwood in 1993 after living for many years in Cambridge. He was 83 .

Originally from Denver, Colorado, he received his A.B. (magna cum laude), A.M., and Ph.D. degrees from the University of Southern California, and his M.P.A. from Harvard. He was a member of Phi Beta Kappa, Phi Kappa Phi, Psi Chi, Epsilon Theta, and Pi Sigma Alpha. He served with the U.S.A.F. during World War II, and then worked in various supervisory capacities with the Social Security Administration in Los Angeles and Baltimore before finally settling in Boston. He was a lecturer at Boston University before joining the Northeastern faculty in 1955 .

Dave was the "founding father" and first director of Northeastern's graduate public administration program, which began in 1969 and by the late 1970s had become one of the largest programs of its type in the country. But Dave was not just a specialist in public administration. He was a man of wide-ranging intellectual interests. He was very knowledgeable in American political thought and taught both graduate and undergraduate courses in that field. And he always maintained a strong interest in philosophy, not just political philosophy but other fields in philosophy as well.

In addition, Dave had a life-long interest in the problems of the aging. In his early years he worked in the Old Age and Survivors Bureau of the federal government, and in his later years he continued to be active in gerontological and public health organizations. He was the chairman of the Council on Aging of Cambridge from 1961 to 1966. He was also chairman of the legislative committee of the Massachusetts Public Health Association in 1965-66, trustee of the Family Service Association of Greater Boston from 1957 to 1960 , and president of the New England Gerontological Association for 1962-63.

Dave was noted for his humanitarian concerns and his dedication to community service. He devoted many hours to Omega Hospice in Somerville and was its chairman. He was an active lay member of Christ Church, Cambridge for 43 years.

Although Dave officially retired in 1975 , he continued to be active in intellectual matters. He taught at Harvard's Institute for Learning and Retirement from its inception in 1977 until this past winter. Here he pursued his interest in philosophy, introducing new topics every year. Despite his active academic and community life, he also found time to play the recorder and pursue his interest in seventeenth-century music. For many years, he faithfully jogged the two miles around Fresh Pond in Cambridge. He was an exceptionally fine colleague who will be greatly missed.

He is survived by his wife Francoise (Thomazeau) and his son, Peter, of Cambridge.

Memorial contributions may be made to Amnesty International or Christ Church, Cambridge.

\section{Gerald Bursey Northeastern University}

\section{Kenneth Farmer}

Kenneth Farmer, associate professor and chair of the department of political science at Marquette University died in Milwaukee on January 13, 1994, at the age of 50. He died of a heart attack brought on by the aggravation of diabetes, a disease with which he struggled for most of his life.

A native of Iowa, Ken taught Soviet politics and Soviet foreign policy, and did research in the areas of Ukrainian nationalism and Soviet administrative elites. He earned his A.B. in political science from Iowa State University, after serving as a language specialist for several years in the Air Force. After Iowa State, Ken moved to the University of Wisconsin, Madison, where he studied with John Armstrong, Melvin Croan, and others.
He earned his M.A. in 1973 and his $\mathrm{Ph} . \mathrm{D}$. in 1977, both in political science. His first appointment was as a one-year replacement at Marquette for the 1977-78 academic year. During that year, the position became permanent, and Ken won the job in competition with a pool of more than 100 applicants. He was promoted and tenured as an associate professor in 1983, and was twice elected department chair by his colleagues, first in 1991, and again, unanimously, in 1993.

Ken's dissertation, later published as Ukrainian Nationalism in the Post-Stalin Era (Martinus Nijhoff, 1980), was a model of painstaking data gathering and insightful interpretation that proved almost prophetic of the changes that were later to occur in the Soviet Union. His subsequent work on Soviet elites, The Soviet Administrative Elite (Praeger, 1992), dealt with a wider range of material, but demonstrated the same analytical and organizational skills.

An accomplished and influential scholar, Ken was also committed to his students, both in the classroom and on the field trips to the Soviet Union that he organized and led in all but two of his years at Marquette. From his arrival on campus, he was one of the department's most respected and popular teachers. His lectures to packed classes on Soviet and Eastern European politics, Soviet foreign policy, and U.S. national security policy were thorough, thoughtful, and professional. The quality of the lectures and his own eagerness to help his students consistently won him the department's highest student evaluations. His trips to the Soviet Union afforded hundreds of young men and women broadening and eye-opening experiences of enduring value for their education in the broadest sense. Ken undertook these trips at some cost to his own health, but his enthusiasm for his students and his fascination with the Soviet Union invariably won out over considerations of prudence.

Although not religious himself, Ken was profoundly respectful of religious faith and of people who lived by it. He was a sensitive man whose difficult childhood robbed 
him of most of life's illusions, and yet left him determined to confront and probe its fundamental questions, which he did regularly with friends, colleagues, and students.

Ken's family and colleagues encourage those wishing to make a donation in his name to consider doing so to a Marquette University department of political science lounge in which many of his books will be housed and students and faculty will be able to meet.

Michael Fleet

James Rhodes

Marquette University

\section{Martin L. Faust}

Martin Faust, Emeritus Professor at the University of MissouriColumbia died on August 13, 1993, at the age of 95 .

Martin was a native of Pennsylvania. After service in the Army infantry in World War 1 , he took his A.B. (1919) and A.M. (1920) at Gettysburg College, where he was a Phi Beta Kappa, and a member of Pi Sigma Alpha. He studied at the University of Pennsylvania for a year, then received a Ph.D. from University of Chicago in 1924, where he was a Political Science Fellow while Leonard White was developing the study of public administration, and Charles Merriam was stimulating students to study state and local government, especially Chicago, in an effort to improve it. Martin continued throughout his life this commitment to good government, especially government with efficient and effective administration.

Martin was an instructor at Gettysburg Academy while working on his M.A. degree, then an instructor at Western Reserve University for a year after studying at Pennsylvania. After completing his Ph.D. at Chicago, he taught for five years at the University of Pittsburgh, then accepted an associate professorship at the University of Missouri in 1929. He also taught summers at Syracuse University, San Jose State College, and the University of Illinois.

He taught at Missouri for 38 years, serving also as chair of the department 1940-49, and 1953-58, and as acting director of the $\mathrm{Bu}$ reau of Government Research in 1959-61. He taught particularly the public administration classes. He was well informed, well organized, conscientious, and careful. After his retirement, the Martin L. Faust Lecture Series on Public Administration was established in his honor.

Martin maintained an active research agenda throughout his career, devoting much of his research to the effort to improve the quality of government. Martin was heavily involved in preparations for the Missouri Constitutional Convention of 1943-44. He prepared an organization manual, and manuals on the legislative article, the executive article, the amending procedure, and the initiative and referendum. After the constitution was adopted, Martin published an evaluation of the constitution after five years, an analysis of the constitution and administrative structure after 19 years, and a history of the adoption of the constitution. Martin also published articles on municipal government, public finance, state government and Missouri government in various journals and books, including The Annals, the Municipal Yearbook, the National Municipal Review, the American Political Science Review, and the Washington University Law Quarterly.

He served for many years as the University's consultant on state and local government matters. $\mathrm{He}$ was director of studies for the Missouri Constitutional Convention, 1943-44, a staff member of the Legislative Research Committee, 1945, a consultant for the State Reorganization Commission of 1955, and a consultant for the Committee on the Executive Branch of the Michigan Constitutional Convention, 1961. He was a member of the Columbia Charter Commission, 194849 , and a member of the city Planning and Zoning Commission and the city Personnel Board. In 1962, the university developed a Local Government Extension program which assumed much of the consulting and public service activities that Martin had conducted over the years.

Martin Faust was a member of the executive council of the American Political Science Association in 1939-41, president of the Missouri Political Science Association, 1963, a member of the Joint Committee, U.S. Department of Agriculture and Land Grant College on Training for Government Service, and a member of the Committee on State Government of the National Municipal League.

Martin married Ann Baker, who preceded him in death in 1974 . She worked many years on issues of public health and city government. She worked to secure city-wide refuse pickup and to reduce water pollution in Columbia through use of biodegradable products. He married Margaret Bolstad in 1975 and she survives. Surviving also is a son, David, of Raytown, a stepson and two stepdaughters, two grandsons and one great-grandchild.

David A. Leuthold
Dean L. Yarwood
University of Missouri-Columbia

\section{Kenneth E. Hofiman}

Kenneth Edward Hoffman, 76, died Tuesday, December 14, 1993 in Morehead, Kentucky. He was a member of the Church of Jesus Christ of Latter Day Saints and was an associate professor of political science of Morehead State University, where he had taught for over 20 years. Also, prior to teaching government, he was elected as a Selectman, Town of Kirby, Vermont, and served in the Vermont legislature. $\mathrm{He}$ is survived by his wife, Janice Inlay Hoffman, two sons and one daughter.

\section{Lindsey Beck Morehead State University}

\section{Albert Lepawsky}

Albert Lepawsky was born in Chicago, Illinois, on February 16, 1908 , the son of Russian Jewish immigrants. He died in Berkeley, California, after a long and debilitating illness in June 1992 at age 84. 